\title{
VARIATIONS IN VELOCITY OF ATHABASCA GLAGIER WITH TIME
}

\author{
By W. S. B. Paterson* \\ (Institute of Earth Sciences, University of British Columbia, Vancouver, Canada)
}

\begin{abstract}
The physical setting of the Athabasca Glacier is described. Ablation of ice from the glacier contributes roughly 40 per cent of the annual outflow from the lake at the terminus. Variations of ice velocity, measured over periods ranging from a week to four months, are discussed. Few if any of these variations can be explained by changes of ice thickness. Variations in the amount of water at the glacier bed provide a plausible explanation however, and the data lend some support to Weertman's ideas on this subject. Variations in annual velocity of the glacier are not correlated with stream flow, but passage of a kinematic wave provides an explanation of these variations. The wave is attributed to a climatic change which began about 1938.
\end{abstract}

RÉsumé. Nous donnons une description du caractère physique du Athabasca Glacier. L'ablation de la glace de ce glacier contribue pour approximativement $40 \%$ dans le débit annuel du lac situé au front du glacier. Nous avons fait des mésures de la vitesse de la glace pendant des périodes d'une semaine à 4 mois. Les variations de l'épaisseur de la glace ne peuvent expliquer qu'une faible partie des variations de la vitesse. Les variations de la quantité de l'eau qui coule sur le lit du glacier donnent une explication vraisemblable. Les mesures vont dans le sens des idées de Weertman sur ce sujet. Les variations de la vitesse moyenne annuelle ne sont pas en correlation avec le débit de la rivière. On peut expliquer ces variations par le trajet d'une vague cinématique. Nous attribuons la vague à une variation climatique qui a commencé en 1938
environ.

Zusammenfassung. Die physikalischen Verhältnisse des Athabasca-Gletschers werden beschrieben. Die Ablation von Gletschereis liefert einen Beitrag von ungefähr $40 \%$ zum jährlichen Abfluss des Sees am Gletscherende. Änderungen der Eisgeschwindigkeit, die über Perioden zwischen einer Woche und 4 Monaten gemessen wurde, werden diskutiert. Nur wenige dieser Änderungen-wenn überhaupt welche-lassen sich durch wechselnde Eisdicken erklären. Änderungen der Wassermenge am Untergrund des Gletschers gestatten eine bessere Erklärung und liefern eine gewisse Bestätigung von Weertman's Ansichten zu dieser Frage. Änderungen in der mittleren Jahresgeschwindigkeit des Gletschers stehen in keiner Beziehung zum Abfluss, doch erlaubt der Durchgang einer kinematischen Welle eine Erklärung dieser Änderungen. Die Welle wird auf eine Klimaänderung zurückgeführt, die etwa 1938 einsetzte.

\section{INTRODUCTION}

In I959 a research project was started on the Athabasca Glacier, Alberta, Canada. The major part of the work was measurement of velocity at depth in bore holes. (Savage and Paterson, 1963; Paterson and Savage, I963[a], [b].) Some data on seasonal variations of surface velocity were also obtained however. The purpose of this paper is to record these data and discuss possible causes of the observed variations. Meteorological data and records of flow of the river draining the lake at the terminus of the glacier are used in the discussion. The velocity data show several features similar to those observed by Elliston (in [Union Géodésique et Géophysique Internationale], I963, p. 65-66) on the Gornergletscher, and support his conclusions.

The Athabasca Glacier (lat. $52 \cdot 2^{\circ}$ N., long. I I $7 \cdot 2^{\circ} \mathrm{W}$.) is one of the main outlet glaciers from the Columbia Icefield in the Canadian Rocky Mountains. The glacier has a simple geometrical shape and is easy of access. The glacier descends from the rim of the Icefield in a series of three ice falls over a distance of $2 \mathrm{~km}$. and continues as a gently sloping tongue of roughly uniform width to a blunt terminus.

All measurements were made in the section between the foot of the lowest ice fall and the terminus. The length of this section is $3.8 \mathrm{~km}$., its average width is $\mathrm{I} \cdot \mathrm{I} \mathrm{km}$., its elevation ranges from $2,300 \mathrm{~m}$. to $\mathrm{I}, 900 \mathrm{~m}$. The only bend is a small one about $\mathrm{I} \mathrm{km}$. from the terminus. The surface slope, generally between 3 degrees and 5 degrees, increases to about i 5 degrees at the terminus. The left (north-west) half of the terminus ends in a glacial lake and is somewhat steeper than this. Ice velocity at the surface decreases from about $75 \mathrm{~m}$./yr. just below the lowest ice fall to $\mathrm{I} 5 \mathrm{~m}$. $/ \mathrm{yr}$. at the terminus. For $2 \mathrm{~km}$. down glacier from the lowest ice fall, ice thicknesses on the centre line are in the range $250 \mathrm{~m}$. to $320 \mathrm{~m}$. Down-glacier from this there are two rises in the bed. The ice then thins rapidly towards the terminus.

* Now with Polar Continental Shelf Project, Department of Mines and Technical Surveys, Ottawa, Canada. 
The equilibrium line is roughly half-way up the highest ice fall at an elevation of about $2,600 \mathrm{~m}$. Glaciers in the area are generally assumed to be temperate. No measurements are available to confirm this and there is some evidence that the assumption is not strictly true (Savage and Paterson, I963, p. 4522; Paterson and Savage, r963[b], p. 4542). Large amounts of melt water flow from under the terminus throughout the summer.

The glacier has crevasses near its sides and also in two small areas, one immediately above the terminus and one about $\mathrm{I} \cdot 5 \mathrm{~km}$. from it. With these exceptions, there are no crevasses below the ice falls. There are two tributary glaciers on the south-east side. Neither is at present joined to the main glacier.

DATA

Measurements of ice velocity

Markers used for velocity measurements consisted of either stakes drilled into the ice or casings in bore holes. Locations of all stakes and bore holes are shown in Figure I. Seasonal velocity data were not obtained for all these markers. Each bore hole is designated by its depth in metres. All bore holes shown except hole i 6 reached the bed of the glacier. The aim was to place the longitudinal line of stakes along the centre line (line of maximum velocity). Subsequent measurements showed that the longitudinal line was about $50 \mathrm{~m}$. to the north-west of the centre line.

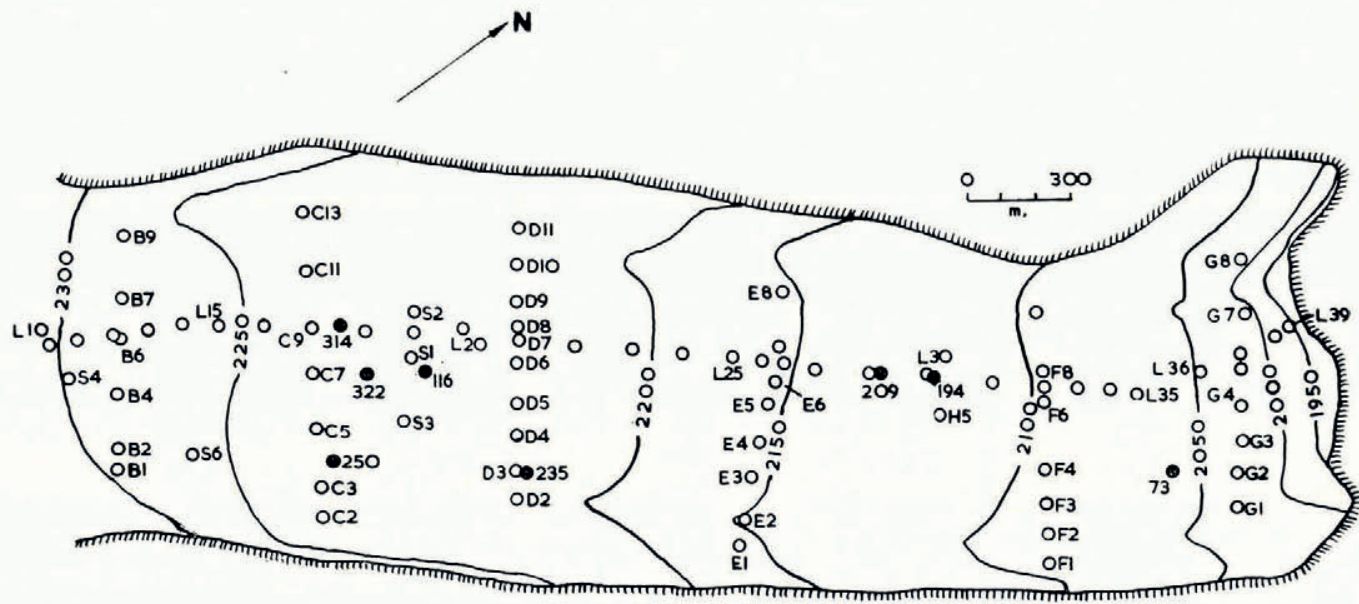

Fig. I. Contour map of lower part of Athabasca Glacier showing stakes (open circles) and bore holes (solid circles)

Velocities were obtained from periodic determinations of the position of each marker by intersection from stations on bedrock. Details of the method and an assessment of the accuracy of the results have been given previously (Paterson and Savage, I963[a]). The majority of the measurements reported here were made between 1959 and I96I.

A difficulty arises from the fact that flow is compressive in that part of the glacier where measurements were made. Thus, as a marker moves down the glacier (relative to the bed), its velocity decreases irrespective of any seasonal change in velocity. However, the longitudinal strain-rate at the surface at points on the centre line could be calculated from differences in velocity between adjacent markers. Surface strain-rates at each bore hole were measured using a diamond-shaped array of stakes. Measurements of velocity of a given marker, made at different times, could thus be reduced to a common point (relative to the glacier bed). This has been done for all data in this paper. Any velocity differences thus represent genuine seasonal effects. 
Stream-flow records

Since i 948, the Water Resources Branch, Department of Northern Affairs and National Resources, has maintained a gauging station on the Sunwapta River at its exit from the lake at the terminus of the glacier. The lake receives run-off from the Athabasca Glacier, its two tributary glaciers, and a glacier on the north side of Mount Athabasca.

The contribution which ablation of ice from the Athabasca Glacier makes to the total run-off can be estimated. Total ablation for 1960 was measured at 12 stakes between the foot of the lowest ice fall and the terminus. The mean was $3.9 \mathrm{~m}$. (water equivalent) with no systematic variation with position. Ablation was not measured in the upper part of the ablation area. A variation, linear with elevation, from $3.9 \mathrm{~m}$. at the foot of the lowest ice fall to zero at the equilibrium line was assumed. The areas of glacier surface lying between different elevations have been determined by Konecny (1964, p. 77). The total run-off from ablation of ice at the glacier surface could thus be calculated. The part of the ablation area where measurements were not made comprised only 30 per cent of the total. Deviations from the assumed linear decrease of ablation with elevation will thus have only a minor effect on the calculated run-off. Melting of ice at the glacier bed and calving of ice into the terminal lake are other sources of ablation. Calculations showed that these were negligible compared with ablation at the surface.

The calculated value of total run-off from ablation of ice in 1960 was $0.014 \mathrm{~km} .{ }^{3}$. Total run-off measured at the gauging station was $0 \cdot 035 \mathrm{~km}$. $^{3}$. Thus, in 1960 , melting of ice from the Athabasca Glacier contributed roughly 40 per cent of the total run-off. It therefore seems reasonable to use recorded variations in stream flow as an indication of variations in run-off from the glacier. In subsequent discussion we are interested, not in total run-off from the glacier, but in the amount of water flowing at the glacier bed. This last quantity cannot be measured. We therefore assume that it is positively correlated with the amount of run-off. In other words, periods of high run-off, as indicated by stream flow records, are assumed to be periods when more than the average amount of water flows at the glacier bed. Some of the conclusions drawn in subsequent sections of this paper rest on this plausible but unproven assumption.

\section{Meteorological records}

In a later section we shall attempt to correlate long-period changes in velocity of the glacier with climatic trends. The weather stations nearest to the glacier are at Lake Louise and Banff, which are II $10 \mathrm{~km}$. and ${ }_{1} 55 \mathrm{~km}$. to the south-east, and at Jasper, $90 \mathrm{~km}$. to the north-west. Records from Banff cover a longer period than the others and have been used in previous studies of fluctuations of the terminus of the glacier (Heusser, I956; Collier, r 958). Records from Banff have therefore been used here also, even although the other stations are nearer the glacier.

For the period I940-6I, mean annual air temperatures at the three stations are very highly correlated $(r=0.8$ to 0.9$)$ and the correlation between annual precipitation at Banff and Lake Louise is significant at the one per cent level. There is no significant correlation between annual precipitation at Jasper and that at the other two stations. However, the climatic trend which is important to the subsequent discussion (increased precipitation between $193^{8}$ and I949) is shown at all three stations. Use of records from one of the other stations would not therefore have changed the conclusions.

\section{Results and Discussion}

Seasonal variations of velocity

The positions of twelve markers were determined in August and November i 960 and in April r96I. The positions of three of the markers were determined again in July 196r. The corresponding velocities and the measured annual velocities are given in Table I. Velocities 
for the periods August to November and November to April do not differ significantly, but are significantly ( 4 to I 3 per cent) less than annual velocities. Mean velocities for the period April to July are about i 5 per cent greater than annual velocities.

Table I. Measured Surface Velocity on Athabasca Glacier

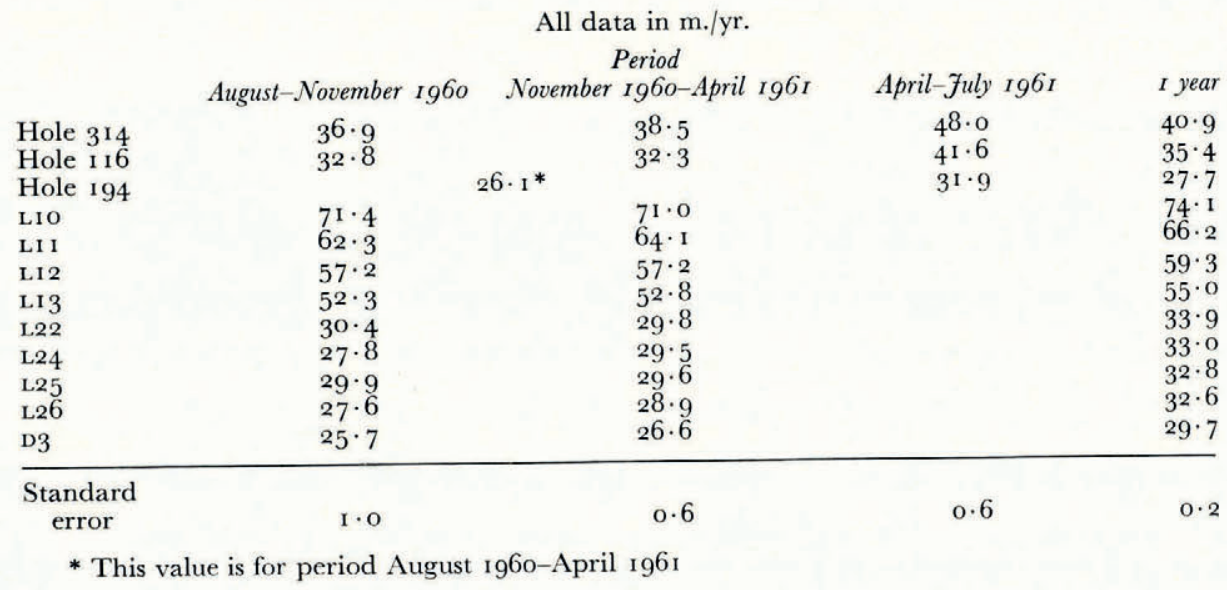

In Table II, velocities for the period August to April are expressed as fractions of annual velocities. Markers are listed in order down the glacier. In general the difference between winter and annual velocity increases with distance down glacier. The last point, hole I94, is an exception. This may perhaps be related to the fact that the glacier becomes narrower at this point. Elliston ([Union Géodésique et Géophysique Internationale], r 963 , p. 65-66) has noted this phenomenon on the Gornergletscher.

Table II. Winter Velocity as Percentage of Annual Velocity

$\begin{array}{lcccccccccccc}\text { Marker } & \text { L1O } & \text { L11 } & \text { L12 } & \text { L13 } & 3^{14} & \text { I16 } & \text { D3 } & \text { L22 } & \text { L24 } & \text { L25 } & \text { L26 } & \text { 194 } \\ \text { Ratio } & 96 & 95 & 96 & 96 & 9^{1} & 9^{1} & 88 & 89 & 87 & 90 & 87 & 93\end{array}$

It is well known that the velocity of a glacier is very sensitive to changes in its thickness. Accumulation and ablation are thus possible causes of seasonal changes in velocity. The annual accumulation on the Athabasca Glacier is not known but it is unlikely that it exceeds the equivalent of $\mathrm{I} \mathrm{m}$. of ice. (Mean annual precipitation at Banff is approximately $0.5 \mathrm{~m}$., water equivalent.) Annual ablation for the year in question was $4.2 \mathrm{~m}$. of ice with no significant variation over the area covered by the markers listed in Tables I and II. In this area, ice thickness on the centre line ranges from $200 \mathrm{~m}$. to $320 \mathrm{~m}$. with a mean of about $275 \mathrm{~m}$. Thus the glacier thickness varies by about 2 per cent during the year.

The shear strain-rate in ice is proportional to the fourth power of the shear stress, and the velocity of flow should be proportional to the fifth power of ice thickness (Nye, I952, p. 84). Changes of thickness might therefore explain seasonal velocity variations of up to io per cent in the present case. The variations listed in Table II are of this order. However the pattern of variation through the year shown in Table $\mathrm{I}$ is unexpected. The thickness of the glacier is at a minimum at the end of August and at a maximum in March. Our data show no difference in velocity between the periods August to November and November to April. The greatest velocity is attained sometime between April and July, when thickness has decreased from its maximum value. Moreover, the mean velocity in this period is 5 per cent greater than annual velocity and this change is too large to be the result of a change of thickness. It is also doubtful 
whether change of thickness could account for the decrease with distance down-glacier of the ratios in Table II. We conclude that changes of ice thickness cannot account for the observed seasonal changes of velocity.

Variations in the velocity with which the glacier slides on its bed, produced by variations in the amount of water available at the bed for lubrication, provide a more reasonable explanation. It might be expected that when ablation starts in April or May melt water will penetrate to the glacier bed in increasing quantities (by draining under the ice from the sides for example). This might produce the increase in velocity observed at this time of year. During the winter, when there is no melt water at the surface, one might expect the velocity to be more or less constant and smaller, as observed. Measurements of velocity made over shorter periods of time enable us to examine this hypothesis in more detail.

\section{Weekly variations of velocity}

Velocities over the periods 2 I July to I5 August and I5 August to I September were measured for $4 \mathrm{I}$ markers. At 39 of them the velocity was significantly greater in the first period than in the second. At one marker (G2) the two velocities were equal. At one marker (L39) the velocity in the second period was the greater. The anomalous behaviour of L39 might be explained by its location some $40 \mathrm{~m}$. from the terminal ice cliff; its velocity was probably controlled by calving of ice into the lake. The ratio of the two velocities at each marker had a mean of $\mathrm{I} \cdot 3$ and a maximum (at D8) of $\mathrm{I} \cdot 8$. No systematic variation with distance down-glacier was apparent.

Such velocities, measured over the periods of two or three weeks, show much greater fluctuations from period to period than do velocities measured over longer intervals of time. This fact has been noted previously by various authors. It is not merely a reflection of greater experimental errors in measurements made over shorter intervals of time.

These variations in velocity are much too great to be explained by the slight decrease in ice thickness due to ablation. The mean daily discharges of the stream draining the terminal lake were $5.01 \mathrm{~m} \cdot 3 / \mathrm{sec}$. and $2.05 \mathrm{~m} .{ }^{3} / \mathrm{sec}$. in the two periods. Thus it is quite likely that more water was flowing at the glacier bed in the first period than in the second, and that the higher observed velocity represents a higher velocity of sliding at the bed.

Velocities over the periods 24 to 3 I July, 3I July to 7 August, and 7 to 14 August were measured for io markers. Of these, 7 were in a transverse line (line $\mathrm{D}$ ) and 3 were bore holes (holes 314,322, I 6 ) at distances up to $0.5 \mathrm{~km}$. up-glacier from the line. Locations are shown in Figure I. Velocities are given in Table III. Velocities in the first week were considerably greater than those in the other two (a factor of roughly $\mathrm{I} \cdot 6$ ). Velocities in the second and third weeks did not differ significantly.

Table III. Weekly Surface Velocities on Athabasca Glacier

All data in m./yr.; standard error is $4 \mathrm{~m} . / \mathrm{yr}$.

\begin{tabular}{|c|c|c|c|}
\hline & $24-31$ July 1960 & $3^{I}$ July -7 August I96o & 7-14 August \\
\hline Hole $3{ }^{1} 4$ & 47 & $3^{8}$ & 40 \\
\hline Hole 322 & 45 & $3^{8}$ & 33 \\
\hline Hole i 16 & 45 & 34 & 37 \\
\hline D3 & $5^{8}$ & 29 & 26 \\
\hline D4 & 43 & 24 & 30 \\
\hline D5 & 66 & $3^{1}$ & 29 \\
\hline D6 & 64 & 33 & 29 \\
\hline D8 & 54 & 27 & 28 \\
\hline D9 & 47 & $3^{2}$ & 30 \\
\hline DIO & 32 & 29 & 25 \\
\hline Mean & $5^{\circ}$ & $3^{I}$ & $3^{1}$ \\
\hline
\end{tabular}


Mean daily stream discharges for each week are given in the first column of Table IV. No correlation with velocity is apparent. However, it is possible that there is some delay between water flowing at the bed of the glacier and its being recorded at the gauge. Succeeding columns in Table V show mean daily discharges for periods of one week starting 3, 4, 6 and 9 days after the days on which positions of the markers were surveyed. The discharge patterns for delays of 3 or 4 days are similar to the velocity patterns. They show a relatively high value in the first week and no appreciable difference between the second and third weeks.

Table IV. Mean Daily Stream Discharge with Delay Times for the Weeks in Table III All data in m.3/sec.

\begin{tabular}{lccccc} 
& \multicolumn{5}{c}{ Delay time in days } \\
& 0 & 3 & 4 & 6 & 9 \\
24-31 July & $5 \cdot 62$ & $6 \cdot 54$ & $6 \cdot 53$ & $6 \cdot 22$ & $5 \cdot 24$ \\
3 I July-7 August & $5 \cdot 79$ & $5 \cdot 21$ & $5 \cdot 35$ & $5 \cdot 75$ & $5 \cdot 76$ \\
7-14 August & $5 \cdot 88$ & $5 \cdot 46$ & $5 \cdot 26$ & $4 \cdot 92$ & $3 \cdot 98$
\end{tabular}

These observations may be relevant to Weertman's theory concerning short-period changes in the velocity of a glacier (Weertman, 1962). Weertman postulates that some of the water at the bed of a glacier flows relatively slowly in the form of a thin sheet. He suggests that shortperiod changes in velocity are caused by changes in the thickness of this sheet. A layer of increased thickness of water will be propagated as a kinematic wave. According to Weertman's calculations, $0.8 \mathrm{~km}$./day is a reasonable velocity for such a wave. On the Athabasca Glacier, the transverse line of markers where velocity was measured is $2 \cdot 4 \mathrm{~km}$. from the terminus. The bore holes listed in Table IV are between 2.7 and $2.9 \mathrm{~km}$. from the terminus. Thus on Weertman's theory, the delay between an observation of increased velocity and increased discharge should be 3 or 4 days, as observed.

These observations thus lend some support to Weertman's ideas. It must be emphasized however that this evidence is indirect. We have assumed that the volume of water flowing at the glacier bed is positively correlated with the measured discharge. Moreover, a demonstration that the glacier velocity is positively correlated with the volume of water flowing at the bed is not in itself any evidence of a causal relationship.

It will be recalled that no delay was introduced in the previous correlation between discharge and velocities measured over periods of 2 and 3 weeks. However, delays of 3 or 4 days are less important for the longer period. Also, the markers in this earlier discussion were distributed over a distance of $3.8 \mathrm{~km}$. Thus no single delay time would have been appropriate.

\section{Annual variations in velocity}

The positions of five bore holes have been determined each July since 1959 or, in two cases, I96o. Velocities are given in Table V. Except for hole 209, which showed small changes from year to year, there were no significant changes of annual velocity between I959 and I962. No explanation is suggested for the anomalous behaviour of hole 209 .

Table V. Annual Surface Velocities on Athabasca Glacier

All data in $\mathrm{m} . / \mathrm{yr}$; ; standard error is $0.2 \mathrm{~m} . / \mathrm{yr}$.

$\begin{array}{lccc} & 1959-60 & 1960-61 & 40 \cdot 3 \\ \text { Hole } 314 & 40 \cdot 7 & 40 \cdot 9 & 38 \cdot 6 \\ \text { Hole } 322 & & 38 \cdot 9 & 35 \cdot 2 \\ \text { Hole } 1 \text { I } 6 & & 35 \cdot 4 & 29 \cdot 5 \\ \text { Hole 209 } & 30 \cdot 9 & 28 \cdot 8 & 27 \cdot 3 \\ \text { Hole } 194 & 28 \cdot 1 & 27 \cdot 7 & \end{array}$

The Water Resources Branch, Department of Northern Affairs and National Resources, have measured velocity annually or biennially since 1945. Results have been given by Davis 
( 1962 ) and are quoted in Table VI. The velocity given is the mean velocity of a line of plaques extending across the glacier about $300 \mathrm{~m}$. from the present terminus (near $\mathrm{L} 36$ in Figure $\mathrm{I}$ ). A new plaque line was established each year. All velocities therefore refer to the same location relative to the glacier bed. Velocities remained constant from I 948 to r 954 , increased steadily until r 958, and remained more or less constant at the new value (about I 35 times the old) thereafter. The Water Resources Branch also measured, by levelling, the transverse profile of the glacier surface at the line of plaques. Between 1947, when the first measurements were made, and $195^{2}$ the level in the central part of the profile decreased with each successive measurement. In I954 the surface returned to about its 1949 level. Levels in $195^{6}$ and $195^{8}$ were approximately the same as in 1952. The level decreased in 1960 and again in 1962; the level in 1962 being approximately $\mathrm{I}$ I $\mathrm{m}$. below that in 1947 . The accuracy of the levelling is not stated, but the main source of error probably arises from the fact that the measurements were made in August which is generally before the end of the ablation season. Thus at least some of the measured variations may merely reflect the fact that ablation was more advanced by the date of measurement in some years than in others. One must be cautious about interpreting these data as an indication of significant changes of thickness of the glacier during these years. It is not known how the surface slope varied.

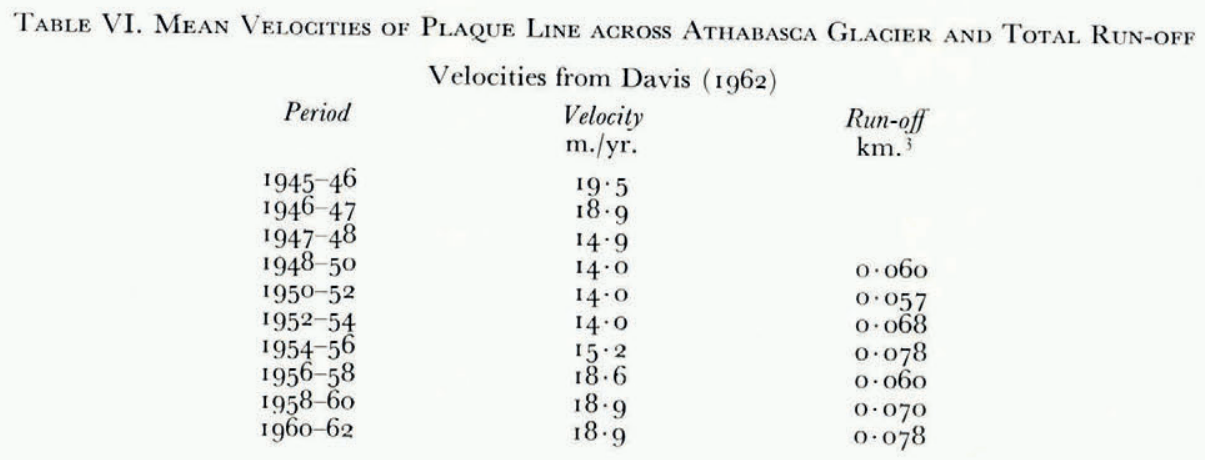

Total run-off, as measured at the gauging station, is also listed in Table VI. The velocity measurements were generally made in early August. Thus each run-off value has been taken for the period starting on I August and ending on 3 I July two years later. There is no correlation between run-off and the velocities listed in Table V and VI. This suggests that, while water at the glacier bed may produce variations of velocity during the year, longer-term variations in velocity must have some other cause. These variations may represent the passage down the glacier of a kinematic wave resulting from a climatic change.

Weather data from Banff (ten-year running means of annual precipitation and of mean annual air temperature) have been reviewed by Heusser (1956, p. 268) and Collier (1958). Precipitation attained a maximum in I9I I. The record shows oscillations thereafter, but the general trend was a decrease to a minimum reached in 1938. Precipitation then increased steadily to a maximum in 1949 . The increase was $\mathrm{I}_{\mathrm{I}} \cdot 2 \mathrm{~cm}$., or 25 per cent of the long-term mean, in I I yr. Precipitation has decreased since I950. Mean annual air temperature was at a minimum in $\mathrm{I}^{\mathrm{I}} 3$ and increased, with fluctuations, to a maximum which was maintained from I 935 to $193^{8}$. Temperature decreased steadily from $193^{8}$ to 1946 , the total fall being $\mathrm{I} \cdot 2^{\circ} \mathrm{C}$. Temperatures remained near this low value until $195^{2}$, and have increased since then.

The most striking trend is that between $193^{8}$ and about $195^{\circ}$ when precipitation increased by 25 per cent and mean annual air temperature dropped by $\mathrm{I}_{2} 2^{\circ} \mathrm{C}$. Collier ( $\left.195^{8}\right)$ has predicted that this trend would eventually produce an advance of glaciers in the Canadian Rockies. This climatic change would favour increased accumulation and decreased ablation 
and one would expect that a wave of increased flow would pass down the glacier. It is suggested that this is the cause of the variations in velocity listed in Table VI. Calculation of the time taken by the wave to reach the terminus supports this idea.

Kinematic waves are expected to travel with velocities of three or four times the ice velocity (Weertman, I958; Nye, I960). From measured velocities of markers L 36 to L39 we can calculate that ice takes about $17 \mathrm{yr}$. to travel from $\mathrm{L} 36$ to the terminus. A kinematic wave should therefore travel there in 4 to $6 \mathrm{yr}$. The increase in velocity was first observed in 1956 . The wave should thus have reached the terminus about 1960 . This is confirmed by the fact that the terminus was effectively stationary between 1960 and 1962 (Davis, 1962). This is the first break in a recession of the glacier which has certainly been maintained since 1945 (Davis, I962) and possibly since I 84I (Heusser, I956, p. 282). It remains to be seen whether the increase in flow is large enough to cause an advance of the glacier or whether it will merely produce a temporary halt in the retreat.

This climatic change at Banff is similar to one in the Pacific North-West discussed by Hubley (1956). Hubley used meteorological data from Tatoosh Island which is on the coast some $720 \mathrm{~km}$. west-south-west of Banff. (Hubley used as ordinate the last year of each ten-year period; Heusser used the middle point. Dates in the present discussion all refer to the middle point.) The data have been extended to 1959 by LaChapelle (1960). For the period I9o8-54, the correlations between ten-year running means of annual precipitation and mean annual air temperature at Tatoosh Island and Banff are 0.50 (for precipitation) and 0.85 (for temperature). Both values are significant at the one per cent level. Between i 939 and I947 annual precipitation at Tatoosh Island increased by about $38 \mathrm{~cm}$. or 20 per cent of the long-term mean. Between $193^{8}$ and $195^{2}$ mean annual air temperature decreased by $0 \cdot 9^{\circ} \mathrm{C}$. The first observed effect of this climatic change on glaciers in the Pacific North-West was a thickening of the Nisqually Glacier near the equilibrium line in 1945 . By $1955,5^{\circ}$ out of 73 glaciers observed in the area were advancing (Hubley, 1956).

These observations illustrate the stronger and more rapid response of small glaciers in a maritime environment, compared with the response of a larger glacier further inland such as the Athabasca Glacier.

\section{Summary}

Measurements were confined to the ablation area.

In general, the shorter the time interval over which measurements were made, the greater were the observed fluctuations of velocity.

Measurements over intervals of 3 or 4 months showed that mean velocities over the period April to July were about i 5 per cent greater than annual velocities. Winter velocities were from 4 per cent to $\mathrm{I} 3$ per cent less than annual velocities. The ratio of winter to annual velocity decreased with increasing distance down the glacier.

Velocities, measured over intervals of 2 or 3 weeks, were on the average 30 per cent greater in the first half of August than in the second half. Velocities in the last week of July were roughly 60 per cent greater than those in either of the next two weeks.

Velocity was positively correlated with stream flow from the lake at the terminus of the glacier. The weekly observations suggested that increased stream flow occurred 3 or 4 days later than an increase in velocity about $2.5 \mathrm{~km}$. up the glacier.

These variations in velocity cannot be explained by variations in thickness of the glacier. An alternative hypothesis is that variations in the amount of water flowing at the bed alter the rate at which the glacier slides on its bed and thus the measured surface velocity. This hypothesis does provide a reasonable explanation of the observations. The delay time, quoted above, supports Weertman's development of this hypothesis.

Annual velocities are correlated neither with stream flow nor with ice thickness. Data from the Water Resources Branch show that annual velocity increased by about 35 per cent 
between 1953 and $195^{8}$. This appears to indicate passage of a kinematic wave. This is attributed to a climatic trend of decreasing air temperature and increasing precipitation which set in about 1938, as shown by weather records at Banff. This is the same trend which, by I955, had caused an advance of many glaciers in the north-western United States.

\section{AGKnowledgements}

Dr. J. S. Stacey and Mr. J. Fairley were responsible for the general organisation of the project in 1959 and I96o respectively. Fairley assisted in velocity measurements in both these years. Mr. W. Ruddy of Snowmobile Tours, Jasper, Alberta deserves special thanks for donating snowmobile time to transport equipment on the glacier, and for assistance in numerous other ways. Thanks are also due to the Director, Water Resources Branch, Department of Northern Affairs and National Resources, for stream-flow data.

The work was financed by grants from the National Research Council of Canada.

MS. received ${ }_{15}$ May ${ }_{1964}$

\section{REFERENCES}

Collier, E. P. 1958. Glacier variation and trends in run-off in the Canadian Cordillera. Union Géodésique et Géophysique Internationale. Association Internationale d'Hydrologie Scientifique. Assemblée générale de Toronto, 3-14 sept. I957. Tom. 4, p. $344^{-57}$.

Davis, D. A. 1962. Survey of glaciers on eastern slope of Rocky Mountains in Banff and Jasper National Parks. Canada. Department of Northern Affairs and National Resources. Water Resources Branch.

Heusser, C. J. 1956. Postglacial environments in the Canadian Rocky Mountains. Ecological Monographs, Vol. 26, No. 4 , p. $263-302$.

Hubley, R. C. I956. Glaciers of the Washington Cascade and Olympic Mountains; their present activity and its relation to local climatic trends. fournal of Glaciology, Vol. 2, No. 19, p. 669-74.

Konecny, G. 1964. Glacial surveys in western Canada. Photogrammetric Engineering, Vol. 30, No. I, p. $64-82$.

LaChapelle, E. R. 1960. The Blue Glacier Project 1959 and 1.96o. Seattle, University of Washington. Department of Meteorology and Climatology.

Nye, J. F. 1952. The mechanics of glacier flow. Journal of Glaciology, Vol. 2, No. 12, p. $82-93$.

Nye, J. F. I960. The response of glaciers and ice-sheets to seasonal and climatic changes. Proceedings of the Royal Society, Ser. A, Vol. 256, No. I287, p. 559-84.

Paterson, W. S. B., and Savage, J. C. 1963[a]. Geometry and movement of the Athabasca Glacier. Fournal of Geophysical Research, Vol. 68, No. 15, p. 4513-20.

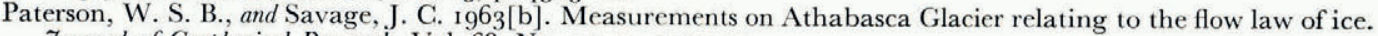
Journal of Geophysical Research, Vol. 68, No. 15, p. 4537-43.

Savage, J. C., and Paterson, W. S. B. 1963 . Bore hole measurements in the Athabasca Glacier. Fournal of Geophysical Research, Vol. 68, No. I5, p. $45^{2} \mathrm{I}-36$.

[Union Géodésique et Géophysique Internationale.] 1963. Colloque d'Obergurgl (suite). Bulletin de l'Association Internationale d'Hydrologie Scientifique, 8e An., No. 2, p. 50-142.

Weertman, J. 1958. Traveling waves on glaciers. Union Géodésique et Géophysique Internationale. Association Internationale d'Hydrologie Scientifique. Symposium de Chamonix, I6-24 sept. 1958, p. 162-68.

Weertman, J. 1962. Catastrophic glacier advances. Union Géodésique et Géophysique Internationale. Association Internationale d'Hydrologie Scientifique. Commission des Neiges et Glaces. Colloque d'Obergurgl, IO-9-18-9 1962, p. 31-39. 